\title{
Controlled Preparation of Different Proportions of Metal Fe-Mn from Waste Mn Ferrite by Molten Salt Electrolysis
}

\author{
Shiyuan Liu ${ }^{1,2}$ and Lijun Wang ${ }^{1, *}$ \\ 1 Collaborative Innovation Center of Steel Technology, University of Science and Technology Beijing, \\ Beijing 100083, China; shiyuanliu126@126.com \\ 2 National Engineering Laboratory for Hydrometallurgical Cleaner Production Technology, \\ Institute of Process Engineering, Chinese Academy of Sciences, Beijing 100190, China \\ * Correspondence: lijunwang@ustb.edu.cn
}

Received: 5 November 2020; Accepted: 7 December 2020; Published: 14 December 2020

\begin{abstract}
A novel method for efficiently recovering Fe and Mn from waste Mn ferrite by molten salt electrolysis is firstly proposed. The electrolysis of molten salt $\left(\mathrm{MnCl}_{2}(1.06 \mathrm{wt} \%)-\mathrm{FeCl}_{3}\right.$ $(2.69 \mathrm{wt} \%)-\mathrm{NaCl}-\mathrm{KCl}$ ) was performed at $800{ }^{\circ} \mathrm{C}$. The phase of product at $2.0 \mathrm{~V}$ was metal $\mathrm{Fe}$ while metal Fe and $\mathrm{Mn}$ were obtained by molten salt electrolysis at $2.3 \mathrm{~V}$. The Fe/Mn mass ratio of electrodeposited products at $2.0 \mathrm{~V}$ and $2.3 \mathrm{~V}$ were 687 and 3.2, respectively. The different proportions of metal Fe-Mn were prepared by controlling the electrolytic voltages. This new method can realize direct transformation of waste Mn ferrite to Fe-Mn alloy.
\end{abstract}

Keywords: metallurgy; metals; waste Mn ferrite; molten salt electrolysis

\section{Introduction}

Ferrites are widely used in the electronics industry [1,2]. Since 2008, more than 250,000 tons of $\mathrm{Mn}-\mathrm{Zn}$ ferrite have been produced annually in China [3]. A large amount of waste ferrite is generated in the manufacturing process of ferrite [3]. Traditional processes for treating waste ferrite included the following procedures: $\mathrm{H}_{2} \mathrm{SO}_{4}$ leaching, reducing, purification, co-precipitation, ball milling, sintering, etc. [4]. The reducing agent used in traditional processes is generally high-purity reduced iron powder [5]. The high price of high-purity iron powder severely affects the application of traditional processes [5]. The development of new processes is very necessary. Chlorination has received increasing attention in the treatment of solid waste and slag [6-10]. The crystal structure of Mn ferrite $\left(\mathrm{MnFe}_{2} \mathrm{O}_{4}\right)$ is spinel [11]. In our previous work, we reported that molten salt chlorination destroyed the spinel structure of $(\mathrm{Mn}, \mathrm{Fe})(\mathrm{Cr}, \mathrm{V})_{2} \mathrm{O}_{4}$ with $\mathrm{AlCl}_{3}$, and then $\mathrm{MnCl}_{2}, \mathrm{CrCl}_{3}, \mathrm{FeCl}_{2}$ and $\mathrm{VCl}_{3}$ were obtained [12,13]. In order to recover the Fe and $\mathrm{Mn}$ in waste ferrite, we propose that the new process includes the following two steps: chlorination of waste $\mathrm{Mn}$ ferrite with $\mathrm{AlCl}_{3}$ and the separation of $\mathrm{Fe}$ and Mn by molten salt electrolysis. Figure 1 shows a flow diagram of a novel method for the utilization of waste Mn ferrite.

After chlorination, $\mathrm{Fe}$ and $\mathrm{Mn}$ in waste $\mathrm{Mn}$ ferrite were present in the form of $\mathrm{FeCl}_{3}$ and $\mathrm{MnCl}_{2}$. The electrodeposition of $\mathrm{Mn}^{2+}$ in a NaCl-KCl system was studied by Xiao et al. [14]. Ye et al. reported the formation of $\mathrm{Mg}$-Li-Mn alloys from $\mathrm{MnCl}_{2}-\mathrm{MgCl} 2-\mathrm{LiCl}-\mathrm{KCl}$ salt [15]. $\mathrm{Fe}_{2} \mathrm{O}_{3}$ was chlorinated by $\mathrm{AlCl}_{3}$, and then metallic Fe was obtained from molten salt containing $\mathrm{FeCl}_{3}$ by molten salt electrolysis [16]. However, the electrolysis and separation of $\mathrm{FeCl}_{3}-\mathrm{MnCl}_{2}-\mathrm{NaCl}-\mathrm{KCl}$ systems has been not reported. In this work, as part of the foundational research on the recovery and separation of Fe and Mn from waste ferrite by a chlorination-electrolysis method, the electrolytic separation of Fe and Mn from $\mathrm{FeCl}_{3}-\mathrm{MnCl}_{2}-\mathrm{NaCl}-\mathrm{KCl}$ molten salt has been studied. 


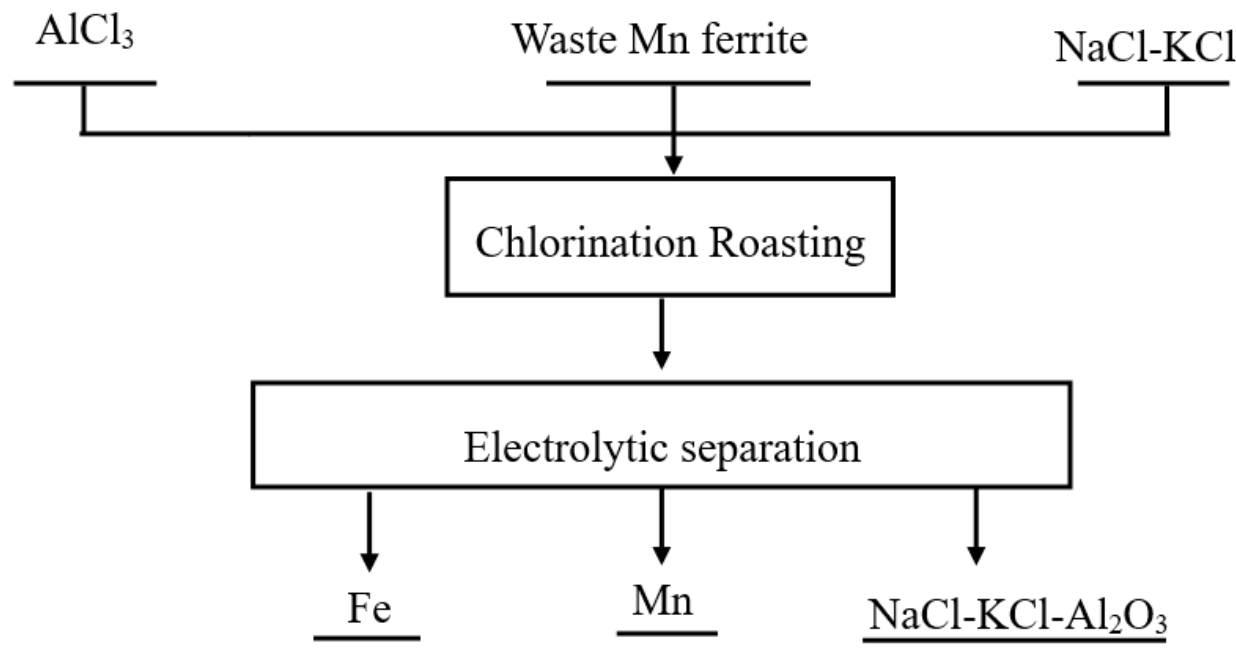

Figure 1. Flow diagram of a novel method for the utilization of waste Mn ferrite.

\section{Materials and Methods}

Analytically pure $\mathrm{NaCl}, \mathrm{KCl}, \mathrm{FeCl}_{3}$ and $\mathrm{MnCl}_{2}$ are used in molten salt electrolysis. Equal molar $\mathrm{NaCl}$ and $\mathrm{KCl}$ were selected as the molten salt medium. The sample with $\mathrm{MnCl}_{2}$ (1.06 wt $\left.\%\right)-\mathrm{FeCl}_{3}$ $(2.69 \mathrm{wt} \%)-\mathrm{NaCl}-\mathrm{KCl}$ was put in a high-temperature furnace, and heated to $800{ }^{\circ} \mathrm{C}$ under the protection of high-purity Ar gas. The electrolysis of Fe and Mn was conducted in a two-electrode cell. A tungsten wire and a graphite rode were used as the cathode material and anode material, respectively. After the electrolysis, the production of cathode surface was washed with deionized water to remove salt $\left(\mathrm{NaCl}, \mathrm{KCl}, \mathrm{FeCl}_{3}\right.$, and $\left.\mathrm{MnCl}_{2}\right)$ from the molten salt medium. The morphology of production was analyzed with a scanning electron microscope (SEM, Zeiss Ultra 55, Oberkochen, Germany). X-ray diffraction (XRD, Rigaku Smartlab, Tokyo, Japan) with a $\mathrm{Cu} \mathrm{K} \alpha$ radiation source was used to identify the phase of the electrodeposited products. To accurately determine the content of Fe and $\mathrm{Mn}$ in the products, the products were dissolved with aqua regia. Then the contents of Fe and $\mathrm{Mn}$ in solution were measured by inductively couple plasma optical emission spectroscopy (ICP-OES, Optima 5300DV, Waltham, MA, USA).

\section{Results and Discussion}

The electrolysis of molten salt $\left(\mathrm{MnCl}_{2}(1.06 \mathrm{wt} \%)-\mathrm{FeCl}_{3}(2.69 \mathrm{wt} \%)-\mathrm{NaCl}-\mathrm{KCl}\right)$ was performed at $800{ }^{\circ} \mathrm{C}$. The decomposition voltages of $\mathrm{FeCl}_{3}$ and $\mathrm{MnCl}_{2}$ are calculated by the following Equations (1)-(4):

$$
\begin{gathered}
\mathrm{Mn}+\mathrm{Cl}_{2}=\mathrm{MnCl}_{2} \\
E_{\mathrm{MnCl}_{2}}=E_{\mathrm{MnCl}_{2}}^{\theta}-\frac{R T}{n F} \ln \frac{\alpha_{\mathrm{MnCl}_{2}}}{\alpha_{\mathrm{Cl}_{2}} \times \alpha_{\mathrm{Mn}}} \\
\mathrm{Fe}+1.5 \mathrm{Cl}_{2}=\mathrm{FeCl}_{3} \\
E_{\mathrm{FeCl}_{3}}=E_{\mathrm{FeCl}_{3}}^{\theta}-\frac{R T}{n F} \ln \frac{\alpha_{\mathrm{FeCl}_{3}}}{\alpha_{\mathrm{Cl}_{2}}^{1.5} \times \alpha_{\mathrm{Fe}}}
\end{gathered}
$$

where $E_{\mathrm{MnCl}_{2}}$ and $E_{\mathrm{FeCl}_{3}}$ are the decomposition voltage of $\mathrm{MnCl}_{2}$ and $\mathrm{FeCl}_{3}$, respectively. $E_{\mathrm{MnCl}_{2}}^{\theta}$ and $E_{\mathrm{FeCl}_{3}}^{\theta}$ are the theoretical decomposition voltage of $\mathrm{MnCl}_{2}$ and $\mathrm{FeCl}_{3}$, respectively. $R$ is the ideal gas constant. $T$ is the temperature in K. $n$ is the number of electrons transferred. $F$ is the Faraday constant. $\alpha_{\mathrm{MnCl}_{2}}$ and $\alpha_{\mathrm{FeCl}_{3}}$ are the activity of $\mathrm{MnCl}_{2}$ and the activity of $\mathrm{FeCl}_{3}$, respectively. $\alpha_{\mathrm{Fe}}$ and $\alpha_{\mathrm{Mn}}$ are the activity of $\mathrm{Fe}$ and the activity of $\mathrm{Mn}$, respectively. $\alpha_{\mathrm{Cl}_{2}}$ is the activity of $\mathrm{Cl}_{2}$.

The activity of $\mathrm{Cl}_{2}$ is assumed to be 1 due to the high-purity Ar gas atmosphere in this experiment. The activity of both metallic Fe and metallic Mn are assumed to be 1 . The concentrations of $\mathrm{FeCl}_{3}$ and 
$\mathrm{MnCl}_{2}$ are used to calculate the decomposition voltages instead of activity, which are attributed to low concentrations of $\mathrm{FeCl}_{3}$ and $\mathrm{MnCl}_{2}$ in $\mathrm{MnCl}_{2}(1.06 \mathrm{wt} \%)-\mathrm{FeCl}_{3}$ (2.69 wt\%)-NaCl-KCl molten salt. The theoretical decomposition voltages of $\mathrm{MnCl}_{2}$ and $\mathrm{FeCl}_{3}$ at $800{ }^{\circ} \mathrm{C}$ are calculated by the Factsage 6.4 program. The theoretical decomposition voltages of $\mathrm{MnCl}_{2}$ and $\mathrm{FeCl}_{3}$ at $800{ }^{\circ} \mathrm{C}$ are $1.8 \mathrm{~V}$ and $0.8 \mathrm{~V}$, respectively. The decomposition voltages of $\mathrm{FeCl}_{3}$ and $\mathrm{MnCl}_{2}$ are calculated by Equations (2) and (4). Thus, the decomposition voltages of $\mathrm{MnCl}_{2}$ and $\mathrm{FeCl}_{3}$ at $800{ }^{\circ} \mathrm{C}$ are $2.3 \mathrm{~V}$ and $1.1 \mathrm{~V}$, respectively. Considering the concentration polarization and electro-chemical polarization, the electrolysis voltages of $2.0 \mathrm{~V}$ and $2.3 \mathrm{~V}$ are selected. The effect of electrolysis time at different voltages and $800{ }^{\circ} \mathrm{C}$ on current is shown in Figure 2. The current vs. time curve shows a similar shape. With a constant voltage of $2.0 \mathrm{~V}$ applied, the current dropped quickly from $1.60 \mathrm{~A}$ to $0.09 \mathrm{~A}$ in seconds, which indicated that the cell voltage achieved equilibrium. As the electrolysis time increased to $8 \mathrm{~min}$, the current gradually increased from 0.09 A to 1.04A. During this electrolysis, metal Fe is deposited on the W cathode, and the surface area of the $\mathrm{W}$ cathode increases. As the electrolysis time increases to $85 \mathrm{~min}$, the current decreases to $0.09 \mathrm{~A}$, which can be attributed to a decreased concentration of $\mathrm{Fe}^{3+}$. Finally, the current drops to about $0.02 \mathrm{~A}$ within $85-125 \mathrm{~min}$ [17]. With a constant voltage of $2.3 \mathrm{~V}$ applied, the current dropped quickly from $2.05 \mathrm{~A}$ to $1.11 \mathrm{~A}$ in seconds. This may correspond to the electrolytic cell of molten salt achieving equilibrium. As the electrolysis time increased to $13 \mathrm{~min}$, the current gradually increased from 1.11 A to 1.30 A. During this electrolysis, metal Fe and Mn are deposited on the $\mathrm{W}$ cathode, and the surface area of the $\mathrm{W}$ cathode increases. As the electrolysis time increases to $60 \mathrm{~min}$, the current decreases to $0.27 \mathrm{~A}$, which can be attributed to a decreased concentration of $\mathrm{Fe}^{3+}$. Finally, the current drops to about $0.16 \mathrm{~A}$ within $60-95 \mathrm{~min}$.

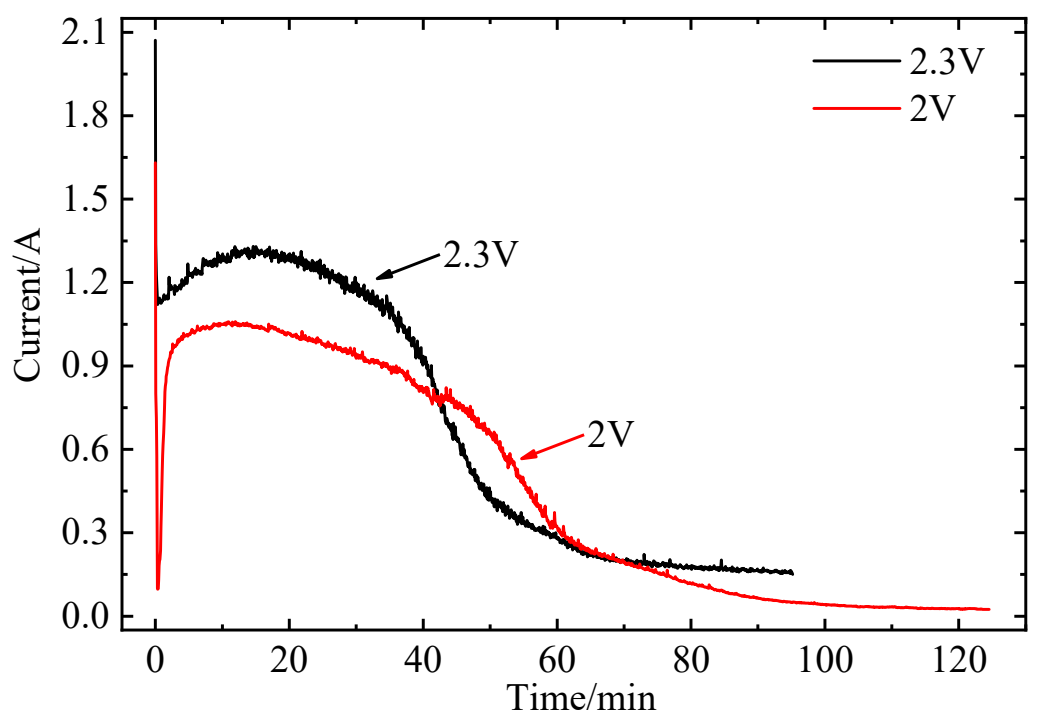

Figure 2. The current-time curve of electrolysis of molten salt $\left(\mathrm{MnCl}_{2}\right.$ (1.06 $\left.\mathrm{wt} \%\right)-\mathrm{FeCl}_{3}$ (2.69 wt $\left.\%)-\mathrm{NaCl}-\mathrm{KCl}, 800{ }^{\circ} \mathrm{C}\right)$.

According to the calculated decomposition voltage, metal Fe was obtained when the electrolysis voltage exceeded 1.1 V. Meanwhile, metal Mn was obtained at voltages exceeding 2.3 V. The XRD in Figure 3 shows that the deposited products at $2.3 \mathrm{~V}$ are metal Fe and Mn. Meanwhile, the deposited product at $2.0 \mathrm{~V}$ is metal Fe. The electrolysis voltage is increased from $2.0 \mathrm{~V}$ to $2.3 \mathrm{~V}$, and $\mathrm{Mn}^{2+}$ ions were electrolyzed to metal Mn. The SEM morphology of the deposited products is shown in Figure 4. The morphology of the product obtained at $2.0 \mathrm{~V}$ is dendritic. The morphology of metal Fe and Mn at $2.3 \mathrm{~V}$ exhibits a stick-like shape. The element contents of Fe and Mn in electrodeposited product were determined using ICP-OES. The Fe/Mn mass ratios of deposited product at $2 \mathrm{~V}$ and $2.3 \mathrm{~V}$ are 687 and 3.2, respectively. Thus, the different proportions of metal Fe-Mn were prepared by controlling the electrolytic voltages. 


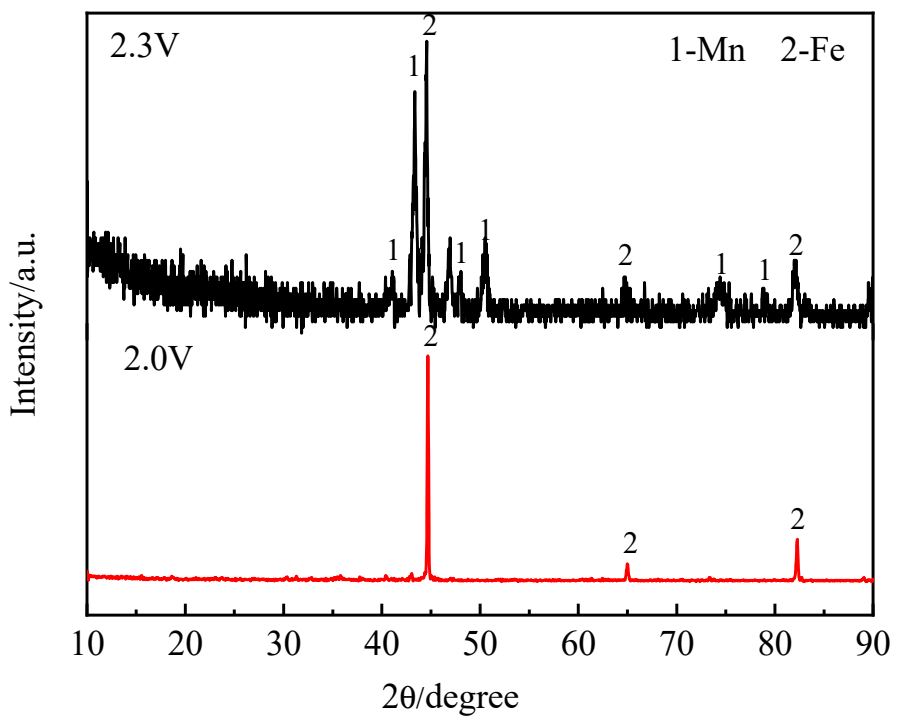

Figure 3. The $\mathrm{XRD}$ analysis of the electrodeposited products by electrolysis with different constant cell voltages $\left(\mathrm{MnCl}_{2}(1.06 \mathrm{wt} \%)-\mathrm{FeCl}_{3}(2.69 \mathrm{wt} \%)-\mathrm{NaCl}-\mathrm{KCl}, 800{ }^{\circ} \mathrm{C}\right)$.

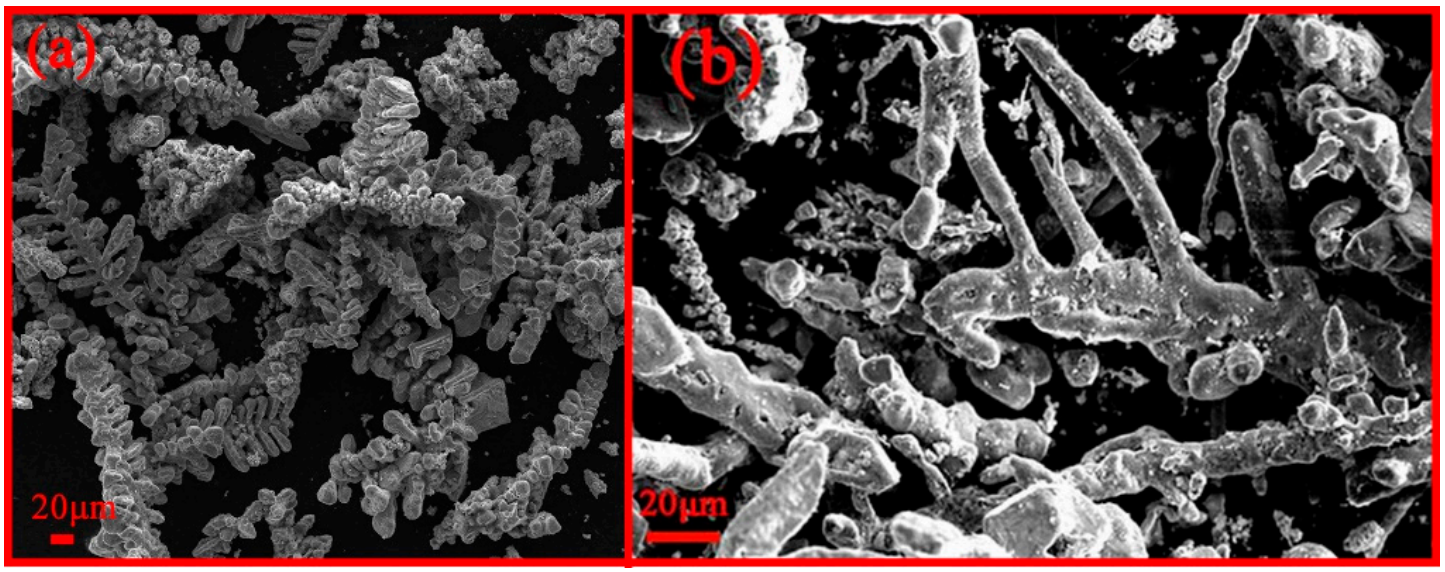

Figure 4. SEM analysis of electrodeposited products under different electrolysis voltages: (a) $2.0 \mathrm{~V}$; (b) $2.3 \mathrm{~V}$.

The economics of this process based on the production of $1 \mathrm{~kg}$ iron is discussed. Energy consumption and material costs were calculated as follows.

The conditions for the controlled preparation of different proportions of metal Fe-Mn by molten salt electrolysis were $2.0 \mathrm{~V}$ at $800{ }^{\circ} \mathrm{C}$ for $125 \mathrm{~min}$. The energy consumption $(\mathrm{Q}, \mathrm{J})$ was obtained through Equation (5) [18].

$$
\mathrm{Q}=\mathrm{C} \times \mathrm{m} \times \Delta \mathrm{T}+\mathrm{K} \times \mathrm{A} \times \Delta \mathrm{T} \times \mathrm{t}-\mathrm{Q}_{\mathrm{r}}+\mathrm{Q}_{\mathrm{r}}^{\prime}+\mathrm{Q}_{\mathrm{e}}
$$

where $C$ is the specific heat of the material, $\mathrm{J} /\left(\mathrm{kg}{ }^{\circ} \mathrm{C}\right) \cdot \mathrm{m}$ is the mass of the material, $\mathrm{kg} . \Delta \mathrm{T}$ is the temperature difference, ${ }^{\circ} \mathrm{C}$. $\mathrm{K}$ is the heat conductivity coefficient, $\mathrm{W} /\left(\mathrm{M}^{2}{ }^{\circ} \mathrm{C}\right)$. A is the superficial area of the reaction vessel, $\mathrm{m}^{2} . T$ is the reaction time, $\mathrm{h} . \mathrm{Q}_{\mathrm{r}}$ is the reaction heat during the reaction process, $\mathrm{J}$. $\mathrm{Q}_{\mathrm{r}}^{\prime}$ is the heat absorbed during the reduction process, $J$. $Q_{\mathrm{e}}$ is the energy consumption during the electro deposition, $\mathrm{J}$.

Postulated conditions: the relationship of the specific heat of $\mathrm{H}_{2} \mathrm{O}\left(\mathrm{C}_{\mathrm{H}}\right), \mathrm{NaCl}\left(\mathrm{C}_{\mathrm{NaCl}}\right)$ and $\mathrm{KCl}$ $\left(\mathrm{C}_{\mathrm{KCl}}\right)$ is described by Equation (6).

$$
\mathrm{C}_{\mathrm{H}}=4 \mathrm{C}_{\mathrm{NaCl}}=4 \mathrm{C}_{\mathrm{KCl}}=4.2 \times 10^{3} \mathrm{~J} /\left(\mathrm{kg}^{\circ} \mathrm{C}\right) .
$$

where $\mathrm{C}_{\mathrm{H}}, \mathrm{C}_{\mathrm{NaCl}}$, and $\mathrm{C}_{\mathrm{KCl}}$ are the specific heat of $\mathrm{H}_{2} \mathrm{O}, \mathrm{NaCl}$, and $\mathrm{KCl}$, respectively. 
According to the Equations (5) and (6), the Equation (7) can be obtained.

$$
\begin{gathered}
\mathrm{Q}=1050 \times 775 \times 129.5+\mathrm{K} \times \mathrm{A} \times 775 \times 2.08+2 \times 1 \times 125 \times 60 \times 2 \times 1345-\mathrm{Q}_{\mathrm{r}}+\mathrm{Q}_{\mathrm{r}}^{\prime}= \\
1.05 \times 10^{8}+\mathrm{K} \times \mathrm{A} \times 775 \times 2.08+4.04 \times 10^{7}-\mathrm{Q}_{\mathrm{r}}+\mathrm{Q}_{\mathrm{r}}^{\prime}
\end{gathered}
$$

where $Q$ is the energy consumption in this process, J. $\mathrm{K}$ is the heat conductivity coefficient, $\mathrm{W} /\left(\mathrm{M}^{2}{ }^{\circ} \mathrm{C}\right)$. A is the superficial area of the reaction vessel, $\mathrm{m}^{2} . \mathrm{Q}_{\mathrm{r}}$ is the reaction heat during the reaction process, $\mathrm{J}$. $\mathrm{Q}_{\mathrm{r}}^{\prime}$ is the heat absorbed during the reduction process, $\mathrm{J}$.

One kilogram of standard coal produces $2.92 \times 10^{7} \mathrm{~J}$. Thus, about $4.8 \mathrm{~kg}$ standard coal (about $5.2 \mathrm{~kg}$ anthracite) was needed. Meanwhile, the price of anthracite is about RMB 900 per ton according to http://www.mycoal.cn. The price of energy consumption for producing $1 \mathrm{~kg}$ Fe is about RBM 4.7.

Molten salt electrolysis in this paper needs $\mathrm{NaCl}$ and $\mathrm{KCl}$. The mass and the cost of materials required to produce $1 \mathrm{~kg}$ Fe is summarized in Table 1 . The prices of the materials originate from https://www.yhs518.com/archives/2956.html. The cost of materials required to produce $1 \mathrm{~kg} F$ about RMB 187. The price of $1 \mathrm{~kg} F$ and $0.5 \mathrm{~kg}$ Mn shown in Table 2 is RMB 9 according to https://www.mysteel.com/.

Table 1. The cost of materials required to produce $1 \mathrm{~kg}$ Fe.

\begin{tabular}{cccc}
\hline Process & Raw Materials & Raw Material Amount/(g) & Cost (RMB) \\
\hline \multirow{2}{*}{ Electrolysis } & $\mathrm{NaCl}$ & 57,056 & 57 \\
& $\mathrm{KCl}$ & 72,488 & 130 \\
\hline
\end{tabular}

Table 2. The price of products.

\begin{tabular}{ccc}
\hline Product & Product Amount/(g) & Price (RMB) \\
\hline $\mathrm{Fe}$ & 1000 & 4 \\
$\mathrm{Mn}$ & 500 & 5 \\
\hline
\end{tabular}

Although the cost of producing $1 \mathrm{~kg} F$ is about $\mathrm{RMB} 191.7, \mathrm{NaCl}$ and $\mathrm{KCl}$ can be reused. No other impurities are introduced during molten salt electrolysis. When the molten salt ratio is $\mathrm{MnCl}_{2}$ (1.06 $\mathrm{wt} \%)-\mathrm{FeCl}_{3}$ (2.69 $\left.\mathrm{wt} \%\right)-\mathrm{NaCl}-\mathrm{KCl}$ for electrolysis, $\mathrm{NaCl}$ and $\mathrm{KCl}$ molten salt can be recycled 22 times to achieve profitability. In fact, the number of cycles of molten salt can be far more than 22 times. At the same time, the content of $\mathrm{MnCl}_{2}$ and $\mathrm{FeCl}_{3}$ in the molten salt is relatively low. When the content of $\mathrm{MnCl}_{2}$ and $\mathrm{FeCl}_{3}$ increases, profits can also be realized. Thus, this process is very industrially promising.

\section{Conclusions}

In summary, the separation of Fe and Mn from waste Mn ferrite by molten salt electrolysis was investigated. The electrolysis of molten salt $\left(\mathrm{MnCl}_{2}(1.06 \mathrm{wt} \%)-\mathrm{FeCl}_{3}(2.69 \mathrm{wt} \%)-\mathrm{NaCl}-\mathrm{KCl}\right) \mathrm{was}$ performed at $800^{\circ} \mathrm{C}$. The phase of product at $2.0 \mathrm{~V}$ is metal $\mathrm{Fe}$, while metal Fe and Mn are obtained by molten salt electrolysis at $2.3 \mathrm{~V}$. The Fe/Mn mass ratio of deposited products at $2.0 \mathrm{~V}$ and $2.3 \mathrm{~V}$ are 687 and 3.2, respectively. Direct extraction of Fe and Mn from waste Mn ferrite was achieved by a chlorination-electrolysis process. This process is simple and effective for the usage of waste Mn ferrite. The chlorination mechanism for waste $\mathrm{Mn}$ ferrite and the electrolysis mechanism for $\mathrm{FeCl}_{3}-\mathrm{MnCl}_{2}$ are the subject of further research.

Author Contributions: Conceptualization, S.L. and L.W.; methodology, S.L.; validation, S.L.; formal analysis, S.L.; investigation, S.L.; resources, S.L.; writing—original draft preparation, S.L.; writing - review and editing, L.W.; visualization, S.L.; supervision, L.W.; funding acquisition, S.L. and L.W. All authors have read and agreed to the published version of the manuscript.

Funding: This research was funded by National Natural Science Foundation of China (No. 51904286, 51922003, 51774027, 51734002) and China Postdoctoral Science Foundation (2019M650848). 
Acknowledgments: The authors are grateful for the financial support of this work from the National Natural Science Foundation of China (No. 51904286, 51922003, 51774027, 51734002), and China Postdoctoral Science Foundation (2019M650848).

Conflicts of Interest: The authors declare no conflict of interest.

\section{References}

1. Liu, S.Y.; Li, S.; Wu, S.; Wang, L.J.; Chou, K.C. A Novel Method for Vanadium Slag Comprehensive Utilization to Synthesize Zn-Mn Ferrite and Fe-V-Cr Alloy. J. Hazard. Mater. 2018, 354, 99-106. [CrossRef] [PubMed]

2. Bollero, A.; Rial, J.; Villanueva, M.; Golasinski, K.M.; Seoane, A.; Almunia, J.; Altimira, R. Recycling of Strontium Ferrite Waste in a Permanent Magnet Manufacturing Plant. ACS Sustain. Chem. Eng. 2017, 5, 3243-3249. [CrossRef]

3. Li, K.K.; Peng, C.H.; Jiang, K.Q. The Recycling of Mn-Zn Ferrite Wastes Through a Hydrometallurgical Route. J. Hazard. Mater. 2011, 194, 79-84. [CrossRef] [PubMed]

4. Bai, B.S. The Study on the Recycling of Waste MnZn Ferrite by Hydrometallurgy-method. Master's Thesis, Central South University, Hunan, China, 2007.

5. Zhu, Y. Study on the Preparation of High Peameability Ferrite Used for Anti-electro-magnetic-interference from MnZn Soft Ferrite Wastes. Master's Thesis, Central South University, Hunan, China, 2011.

6. Du, G.C.; Fan, C.L.; Yang, H.T.; Zhu, Q.S. Selective Extraction of Vanadium from Pre-oxidized Vanadium Slag by Carbochlorination in Fluidized Bed Reactor. J. Clean. Prod. 2019, 237, 117765. [CrossRef]

7. Liu, S.Y.; Wang, L.J.; Chou, K.C. Selective Chlorinated Extraction of Iron and Manganese from Vanadium Slag and Their Application to Hydrothermal Synthesis of $\mathrm{MnFe}_{2} \mathrm{O}_{4}$. ACS Sustain. Chem. Eng. 2017, 5, 10588-10596. [CrossRef]

8. Ma, E.; Lu, R.X.; Xu, Z.M. An efficient rough vacuum chlorinated separation method for the recovery of indium from waste liquid crystal display panels. Green Chem 2012, 14, 3395-3401. [CrossRef]

9. Carbral-Pinto, M.M.S.; Inácio, M.; Neves, O.; Almeida, A.A.; Pinto, E.; Oliveiros, B.; Silva, E.A.F.D. Human Health Risk Assessment Due to Agricultural Activities and Crop Consumption in the Surroundings of an Industrial Area. Expos. Health 2020, 12, 629-640. [CrossRef]

10. Carbral-Pinto, M.M.S.; Marinho-Reis, P.; Almeida, A.; Pinto, E.; Neves, O.; Inácio, M.; Gerardo, B.; Freitas, S.; Simões, M.R.; Dinis, P.A.; et al. Links between Cognitive Status and Trace Element Levels in Hair for an Environmentally Exposed Population: A Case Study in the Surroundings of the Estarreja Industrial Area. Int. J. Environ. Res. Public Health 2019, 16, 4560. [CrossRef] [PubMed]

11. Liu, S.Y.; Wang, L.J.; Chou, K.C. Synthesis of Metal-Doped Mn-Zn Ferrite from the Leaching Solutions of Vanadium Slag Using Hydrothermal Method. J. Magn. Magn. Mater. 2018, 449, 49-54. [CrossRef]

12. Liu, S.Y.; Wang, L.J.; Chou, K.C. A Novel Process for Simultaneous Extraction of Iron, Vanadium, Manganese, Chromium, and Titanium from Vanadium Slag by Molten Salt Electrolysis. Ind. Eng. Chem. Res. 2016, 55, 12962-12969. [CrossRef]

13. Liu, S.Y.; Wang, L.J.; Chou, K.C.; Kumar, R.V. Electrolytic Preparation and Characterization of VCr Alloys in Molten Salt from Vanadium Slag. J. Alloy. Comp. 2019, 803, 875-881. [CrossRef]

14. Xiao, S.J.; Liu, W.; Gao, L. Cathodic Process of Manganese (II) in NaCl-KCl Melt. Ionics 2016, 22, $2387-2390$. [CrossRef]

15. Ye, K.; Zhang, M.L.; Chen, Y.; Han, W.; Yan, Y.D.; Wei, S.Q.; Chen, L.J. Study on the Preparation of Mg-Li-Mn Alloys by Electrochemical Codeposition from LiCl- $\mathrm{KCl}-\mathrm{MgCl}_{2}-\mathrm{MnCl}_{2}$ Molten Salt. J. Appl. Electrochem. 2010, 40, 1387-1393. [CrossRef]

16. Haarberg, G.; Kvalheim, M.E.; Rolseth, S.; Murakami, T.; Pietrzyk, S.; Wang, S.L. Electrodeposition of Iron from Molten Mixed Chloride/Fluoride Electrolytes. ECS Trans. 2007, 3, 341-345. [CrossRef]

17. Zou, X.L.; Lu, X.G.; Li, C.H.; Zhou, Z.F. A Direct Electrochemical Route from Oxides to Ti-Si Intermetallics. Electrochim. Acta 2010, 55, 5173-5179. [CrossRef] 
18. Wang, H.G.; Zhang, M.; Guo, M. Utilization of Zn-Containing Electric Arc Furnace Dust for Multi-Metal Doped Ferrite with Enhanced Magnetic Property: From Hazardous Solid Waste to Green Product. J. Hazard. Mater. 2017, 339, 248-255. [CrossRef] [PubMed]

Publisher's Note: MDPI stays neutral with regard to jurisdictional claims in published maps and institutional affiliations.

(C) 2020 by the authors. Licensee MDPI, Basel, Switzerland. This article is an open access article distributed under the terms and conditions of the Creative Commons Attribution (CC BY) license (http://creativecommons.org/licenses/by/4.0/). 